\title{
Histomorphological Changes in the Mammary Gland of Local Indian Goat during Lactation Cycle
}

\author{
Rakhi Vaish, J.S. Taluja, Nidhi Gupta, Yogita Pandey, Payal Jain, Shashi Tekam
}

10.18805/ag.D-5395

\begin{abstract}
Background: In developing countries goat rearing is the sustainable source of income for marginal farmers. The goat milk contains lower fat per cent $(3.5 \%)$ as compared to cow $(4.1 \%)$ and buffalo milk $(7.4 \%)$, with smaller and homogenous fat globules. It is suitable for the persons with poor digestibility of cow milk and infants having mother milk intolerance. To improve the milk production it is important to understand the mammary gland pattern during the different phases of lactation. The present study aimed at analyzing these changes by histological and histochemical observations. The mammary gland is composed of parenchyma containing acini and stroma including the ductual system. These components change during the lactation cycle.

Methods: The present study was conducted on 24 goats, eighteen in lactating stage where as six from nonlactating stage. The mammary glands were collected from local abattoir with known history of stage of lactation and divided into three groups as early lactation (2-4 weeks), mid lactation (5-6 weeks) and late lactation (> 6 weeks). The histological and histochemical studies were performed during the different stages of lactation and in non lactating stage to observe the morphological and morphometrical changes along with the presence and absence of different components.

Result: The lobules of the mammary gland were polygonal, triangular, oval or elongated in shape during early lactation stage. Approximately all the alveoli observed in early lactation were filled with variable quantity of eosinophilic substance and appeared foamy, due to presence of variable size of fat vacuoles. In mid lactation the lobules became highly irregular. The long and short diameter of lobules was $1041.69 \mu \mathrm{m}$ and $563.93 \mu \mathrm{m}$, respectively. The intralobular stroma was inconspicuous hence alveolar wall appeared to touch each other. In late lactation lobules became shorter in size. The large alveoli showed folded and collapsed appearance. In nonlactating stage well defined alveoli, clusters of desquamated cells were seen and degenerated alveoli were also observed. These histomorphological changes in the secretory unit of the mammary gland reflect the lactation yield and milk composition during different stages of lactation.
\end{abstract}

Key words: Goat, Histology, Lactating, Mammary gland, Nonlactating.

\section{INTRODUCTION}

In developing countries goat rearing is the sustainable source of income for marginal farmers. Recently the demand for goat milk increased due to its medicinal properties. It contains lower fat per cent $(3.5 \%)$ as compared to cow $(4.1 \%)$ and buffalo milk $(7.4 \%)$, with smaller and homogenous fat globules (Banerjee, 2011). It is suitable for the persons with poor digestibility of cow milk and infants having mother milk intolerance (ICAR, 2011). The growth rate of mammary gland increases following puberty, gets greatly accelerated during pregnancy, reaches its greatest development during lactation period and involutes at the end of the lactation period (Dellmann and Eurell, 1998). Concerning the lactation period, it differs between small ruminant species. In goat, the lactation period lasts for 10 months with a peak between weeks 5 and 10 (Salama et al., 2005). The lactogenesis process helps to systematize and highlight the various morphological mammary gland patterns during lactation. The strong relation between the lactation curve and different patterns in the mammary gland necessitates the need for increasing the knowledge of association of specific periods of cell proliferation/decline with the lactation cycle. Very few authors studied the modification occurring in the mammary gland during the
Department of Veterinary Anatomy, College of Veterinary Science and Animal Husbandry, Jabalpur-482 001, Madhya Pradesh, India.

Corresponding Author: Rakhi Vaish, College of Veterinary Science, Nanaji Deshmukh Veterinary Science University, Jabalpur482 001, Madhya Pradesh, India. Email: vaishdr.rakhi@yahoo.in

How to cite this article: Vaish, R., Taluja, J.S., Gupta, N., Pandey, Y., Jain, P. and Tekam, S. (2022). Histomorphological Changes in the Mammary Gland of Local Indian Goat during Lactation Cycle. Agricultural Science Digest. DOI: 10.18805/ag.D-5395.

Submitted: 31-05-2021 Accepted: 10-11-2021 Online: 25-01-2022

lactation period in small ruminants. Considering the current importance of goat milk production, the present study has been undertaken to highlight the alteration in the morphological and morphometrical pattern of mammary gland underlying milk production during the lactation cycle and in nonlactating goats. Moreover, these data will be important in supporting further studies aimed at improving lactation yield and mastitis prevention, among other factors, to benefits the emerging dairy sector from both industry and consumer point of view. 


\section{MATERIALS AND METHODS}

The present study was conducted in 24 goats, eighteen in lactating stage and six in nonlactating stage. The mammary glands were collected from local abattoir with known history of stage of lactation and divided into three groups as early lactation (2-4 weeks), mid lactation (5-6 weeks) and late lactation (>6 weeks). After gross examination the glands were fixed in 10 per cent buffered formalin. The fixed tissue samples were processed in Acetone-Benzene sequence for preparation of paraffin blocks. Five to six micron $(m)$ thick paraffin sections were cut with the help of rotary microtome (Spencer), mounted on clean albuminized glass slides and stained with Haematoxylin and Eosin stain for normal histological studies and stained with Masson's Trichrome, Van Gieson's, Weigert's elastic and Verhoeff's elastic stain for connective tissue fibers Gomori's reticulin method for reticular fibers, modified vonkossa method for calcium, Perl's Prussian blue for ferric iron, best carmine for glycogen and Mercury Bromophenol blue for protein (Pearse, 1968). Micrometry was done for different parameters of alveoli and duct system.

\section{RESULTS AND DISCUSSION}

\section{Lactating mammary gland}

The mammary gland parenchyma and stroma organized into units- lobes and lobules as the basic structural component. Parenchyma of the mammary gland comprised of alveoli and ducts present in the lobules (Fig 1A). The morphology and morphometry in three phases of lactation are:

\section{Early lactation (2-4 weeks)}

The lobules of the mammary gland were polygonal, triangular, oval or elongated in shape (Fig 1A). The long and short diameter of lobules were $1351.84 \mu \mathrm{m}$ and 720.12 $\mu \mathrm{m}$, respectively (Table 1 ). The alveoli in a lobule were present in different stages of functional activity. Approximately all the alveoli observed in early lactation were filled with variable quantity of eosinophilic substance and appeared foamy, due to presence of variable size of fat vacuoles (Fig 2A). This observation supports the finding of Strzalkowska et al. (2009). They analyzed that during the early stage of lactation dairy goats may suffer with negative energy balance and variable degree of lipolysis in the fatty tissue increasing the level of free fatty acids that have a negative effect on palatibility traits of milk. The mean long and short diameter of alveoli in early lactation were 112.30 $\mu \mathrm{m}$ and $76.40 \mu \mathrm{m}$, respectively with the mean long and short diameter of lumen as $89.19 \mu \mathrm{m}$ and $57.49 \mu \mathrm{m}$. The average number of alveoli was 78 per lobule and each alveolus was lined with single layer of high cuboidal/low columnar epithelium with a height of $9.37 \mu \mathrm{m}$. The average number of cells present in each alveolus was 21 (Table 1). The nuclei of the alveolar epithelium were large round or oval with average diameter of the round nuclei was $5.46 \mu \mathrm{m}$ (Table 1). The basement membrane of the alveoli was comprised of network of reticular fibers.

The interlobular stroma was comprised predominantly of collagenous and elastic fibers. The collagen fibers formed dense bundles. Fine elastic fibers were also demonstrated in early lactation (Fig 2B). The interlobular septae were continuous with the capsule of the gland. The intralobular stroma was more prominent encircling the alveoli and intralobular ducts (Fig 2A). This loose stroma was more delicate than the interlobular stroma. There was a narrow and distinct layer of fine collagen fibers around the alveoli. Which were prominent and thicker around the intralobular duct (Fig 3A). Elastic fibers were not noticeable in the intralobular stroma (Fig 4B). Reticular fibers were also appreciable.

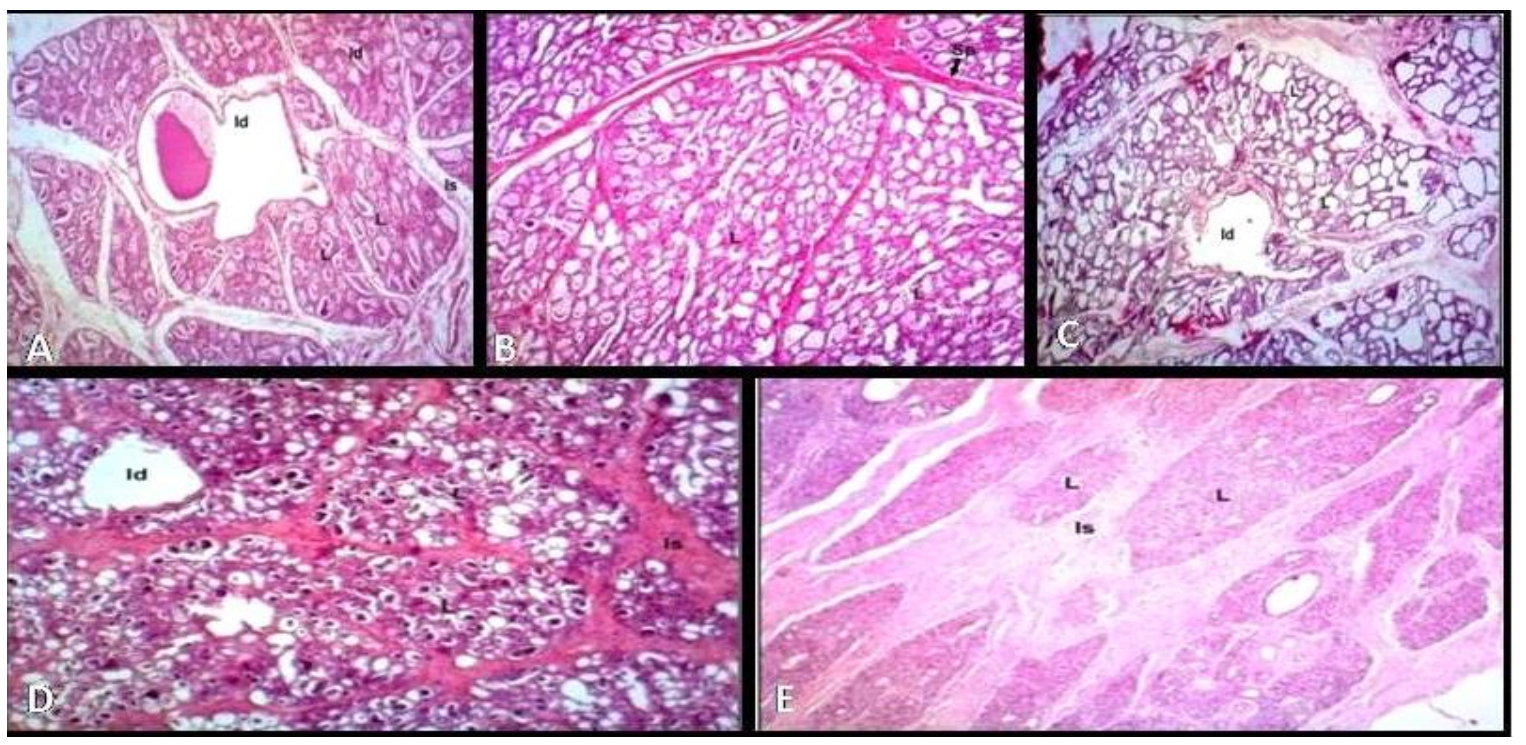

Fig 1A: Photomicrograph cross section of mammary gland in different stage of lactation and non lactation (dry period) showing different shape of lobules (L), interlobular stroma (Is), large interlobular duct (Id), intralobular ducts (id) and dense septae (Sp). A and B: Early Lactation. C: Mid lactation. D: late lactation. E: Non lactation, (H\&EX40). 


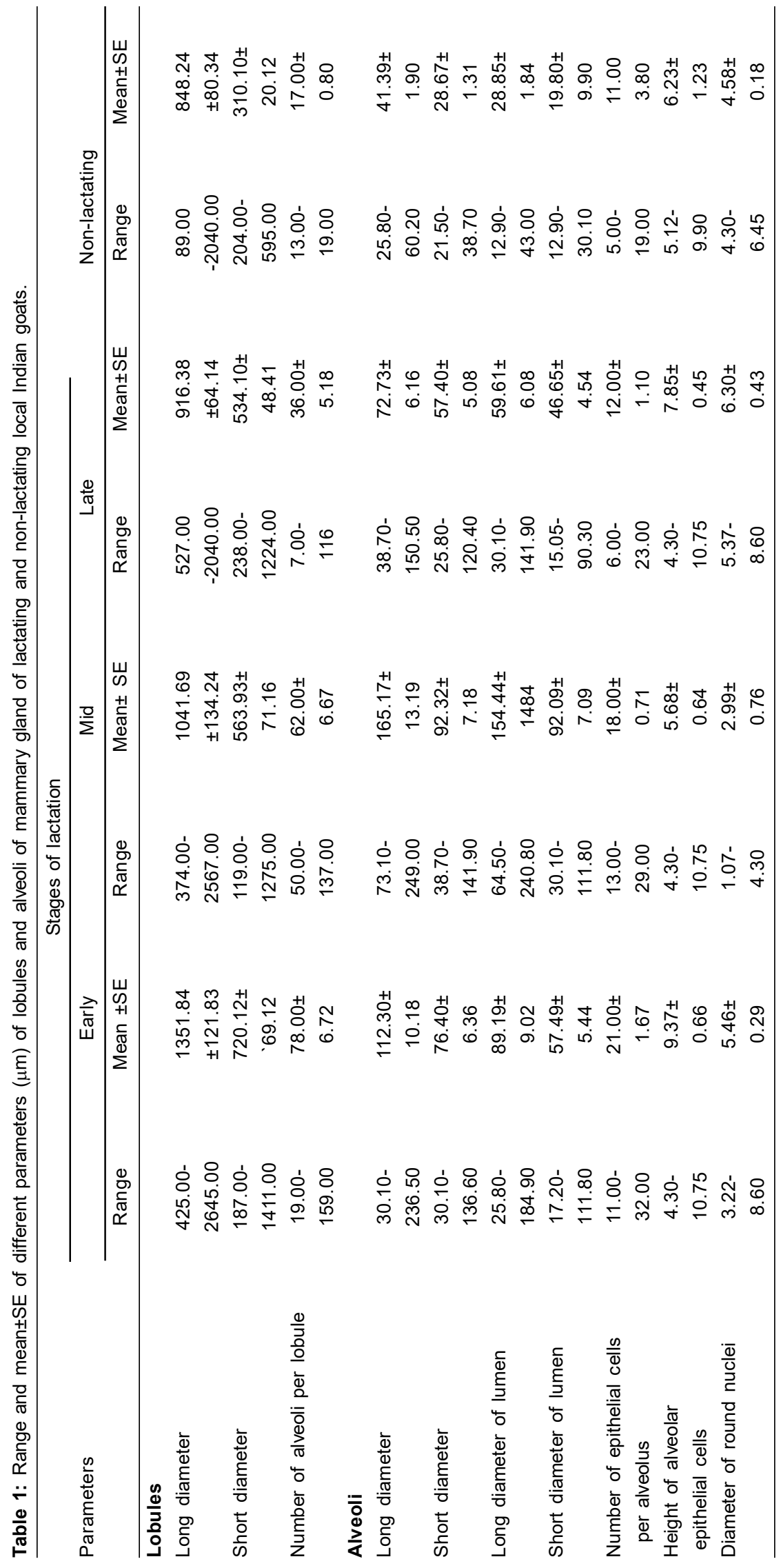


Table 2: Range and mean \pm SE of diameter of lumen and height $(\mu \mathrm{m})$ of epithelium of intralobular ducts of lactating and non-lactating mammary gland in local Indian goat.

\begin{tabular}{|c|c|c|c|c|c|c|c|c|}
\hline \multirow{3}{*}{ Parameters } & \multicolumn{6}{|c|}{ Stages of lactation } & \multirow{2}{*}{\multicolumn{2}{|c|}{ Non-lactating }} \\
\hline & \multicolumn{2}{|c|}{ Early } & \multicolumn{2}{|c|}{ Mid } & \multicolumn{2}{|c|}{ Late } & & \\
\hline & Range & Mean \pm SE & Range & Mean \pm SE & Range & Mean \pm SE & Range & Mean $\pm S E$ \\
\hline \multicolumn{9}{|l|}{ Lumen diameter } \\
\hline Long & $\begin{array}{l}235.00- \\
327.00\end{array}$ & $\begin{array}{c}289.67 \pm \\
26.55\end{array}$ & $\begin{array}{c}290.00 \pm \\
364.50\end{array}$ & $\begin{array}{c}342.00 \pm \\
17.32\end{array}$ & $\begin{array}{l}133.30- \\
305 . .30\end{array}$ & $\begin{array}{c}258.22 \pm \\
26.56\end{array}$ & $\begin{array}{r}137.60- \\
292.40\end{array}$ & $\begin{array}{c}221.14 \pm \\
24.36\end{array}$ \\
\hline Short & $\begin{array}{l}95.50- \\
185.00\end{array}$ & $\begin{array}{c}170.70 \pm \\
12.12\end{array}$ & $\begin{array}{l}94.10- \\
191.00\end{array}$ & $\begin{array}{c}187.19 \pm \\
27.31\end{array}$ & $\begin{array}{l}81.30- \\
164.40\end{array}$ & $\begin{array}{c}86.83 \pm \\
9.97\end{array}$ & $\begin{array}{l}86.00- \\
124.70\end{array}$ & $\begin{array}{c}119.19 \pm \\
9.95\end{array}$ \\
\hline Height of epithelium & $\begin{array}{l}7.20- \\
12.90\end{array}$ & $\begin{array}{c}8.60 \pm \\
0.58\end{array}$ & $\begin{array}{l}8.60- \\
12.90\end{array}$ & $\begin{array}{c}8.10 \pm \\
0.67\end{array}$ & $\begin{array}{l}4.30- \\
8.60\end{array}$ & $\begin{array}{c}6.45 \pm \\
0.89\end{array}$ & $\begin{array}{l}5.80- \\
6.35\end{array}$ & $\begin{array}{c}6.32 \pm \\
0.39\end{array}$ \\
\hline
\end{tabular}

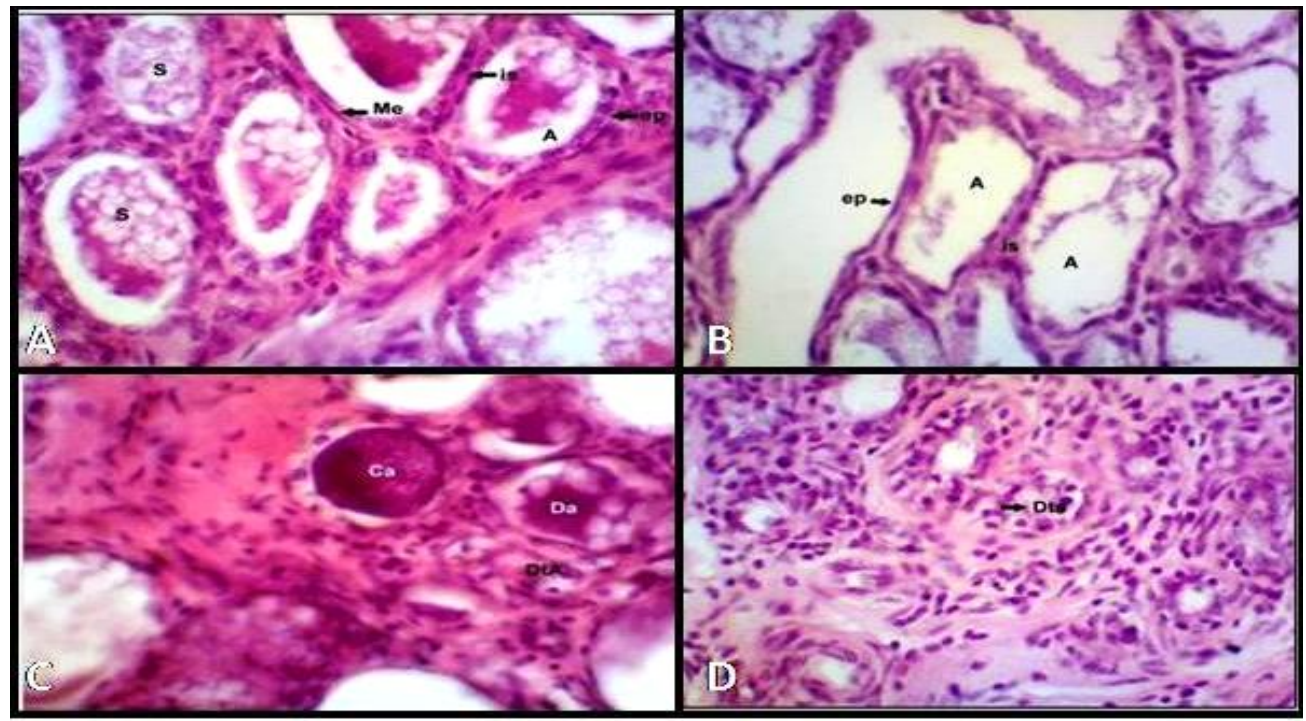

Fig 2: Photomicrograph-cross section of mammary gland showing alveoli at different stage of lactation and non lactation (dry period). A: Early lactation alveoli (A) lined by simple cuboidal epithelium and thick intralobular stroma (Is) B: mid lactation, irregular alveoli (A) lined by low cuboidal epithelium C: late lactation showing degenerating alveoli with corpora amylacea (Ca) D: non lactating showing degenerated alveoli, (H \& EX400).

\section{Mid lactation (5-6weeks)}

In mid lactation the lobules became highly irregular (Fig 1C). The long and short diameter of lobules was $1041.69 \mu \mathrm{m}$ and $563.93 \mu \mathrm{m}$, respectively. The average number of alveoli was 62 per lobule in mid lactation. Most of the alveoli were highly distended with irregular shape (Fig 2B) and long and short diameter of $165.17 \mu \mathrm{m}$ and $92.32 \mu \mathrm{m}$, respectively. The mean long and short diameter increased from early to mid lactation. The present observation was in agreement with the finding of Michel (1981) in cow. The epithelial height of the alveoli was $5.68 \mathrm{~mm}$. This reduction in height of the epithelium in mid lactation is in agreement with the finding of Riviere (2007). He reported that a fully lactating udder form in animal killed just previous to milking time, the alveoli were widely distended with markedly flattened cells having widely separated nuclei. The average number of cells present in each alveoli was 18 . The nuclei were, round, oval or flattened with $2.99 \mu \mathrm{m}$ average diameter (Table 1).
Interlobular stroma was thin composed of bundles of collagen fibers along with elastic fibers. Due to the thin interlobular stroma, the interlobular duct appeared to have more proximity to the lobules. The intralobular stroma was inconspicuous hence alveolar wall appeared to touch each other. Reticular fibers were observed in basement membrane (Fig 4C).

\section{Late lactation ( $>6$ weeks)}

In late lactation lobules became shorter in size (Fig 1D). The greater number of lobules were in resting stage. The average long and short diameter of lobule was $916.38 \mu \mathrm{m}$ and $534.10 \mu \mathrm{m}$, respectively. Most of the alveoli were round in shape and were much smaller than early and mid lactation. The mean long and short diameter of alveoli was $72.73 \mu \mathrm{m}$ and $57.40 \mu \mathrm{m}$, respectively (Table 1 ). The average number of alveoli present in each lobule was 36. Corpora amylacea were noticed in most of the alveoli. The large alveoli showed folded and collapsed appearance. Further, the involution 
was associated with a decrease in the number of alveoli, exaggeration of their folded appearance, increase in intralveolar connective tissue and obvious ducts (Fig $2 \mathrm{C}$ ). This observation is in agreement with the findings of Reece (1958) who noticed that during involution the alveoli collapsed with disintegrated epithelial cells which shed into the lumina. The number of cells in each alveoli was 12 . The decreasing trend of number of cell was in consonance with the finding of Knight and Wilde (1993). They found that the number of secretory cells in the udder of goats decreased as lactation advanced, but cell activity remained unchanged. The epithelial height of the alveoli was $7.85 \mathrm{~mm}$ (Table 1). The interlobular and intralobular stroma was much thicker than in early and mid lactation.

It was evident that stage of lactation affects the chemical composition of produced milk (Gonzolo et al., 1994). Mestawet et al. (2012) found that fat contents were significantly higher at the early stage and late stages of lactation. The present finding is in line with the above statement because in late stage also fat vacuoles were seen in the alveoli and ducts. However, other authors found that fat contents decreased significantly with the progress of lactation.

\section{Intralobular and Interlobular ducts}

The alveoli in a lobule drain their secretion into intralobular ducts. These were lined by simple cuboidal epithelium. The nuclei were round in early lactation where as in mid lactation some of nuclei were flattened (Fig 3A, 2B). The mean long diameter of intralobular ducts in early, mid and late lactation was $289.67 \mu \mathrm{m}, 342.00 \mu \mathrm{m}$ and $258.22 \mu \mathrm{m}$, respectively. The average height of epithelium in early, mid and late lactation was $8.60 \mu \mathrm{m}$ and $8.10 \mu \mathrm{m}$ and $6.45 \mu \mathrm{m}$, respectively (Table 2). In early lactation sufficient amount of stroma was present between the interlobular duct and adjacent alveoli with a clear distinction between the two. In mid lactation the subepithelial storma was negligible. Spindle shaped myoepithelial cells were present between the epithelial lining and basement membrane (Fig 3A).

The interlobular ducts were found in the interlobular septae of connective tissue. These were lined by bistratified epithelium. The luminal layer was composed of high cuboidal cells where as the basal layer was comprised of flattened epithelial cells. The mean long diameter of interlobular duct in mid lactation was maximum $(2214.00 \mathrm{~mm})$. This greater diameter of interlobular and intralobular duct might be indicative of the greater secretory activity and carrying capacity of the ducts system in lactating goats.

The average height of the epithelium in early and mid lactation was $8.60 \mu \mathrm{m}$ and $10.76 \mu \mathrm{m}$, respectively (Table 3 ). The lamina propria was composed of collagen and elastic fibers. The elastic fibers were thin and concentrated near the lamina propria. In late lactation the lamina propria was thick (Fig 3B).

\section{Nonlactating mammary gland}

In nonlactating nonpregnant goat the lobules were elongated and oval in shape. These lobules were separated by large amount of interlobular stroma and were smaller than that of the lactating goats (Fig 1E). The average long and short

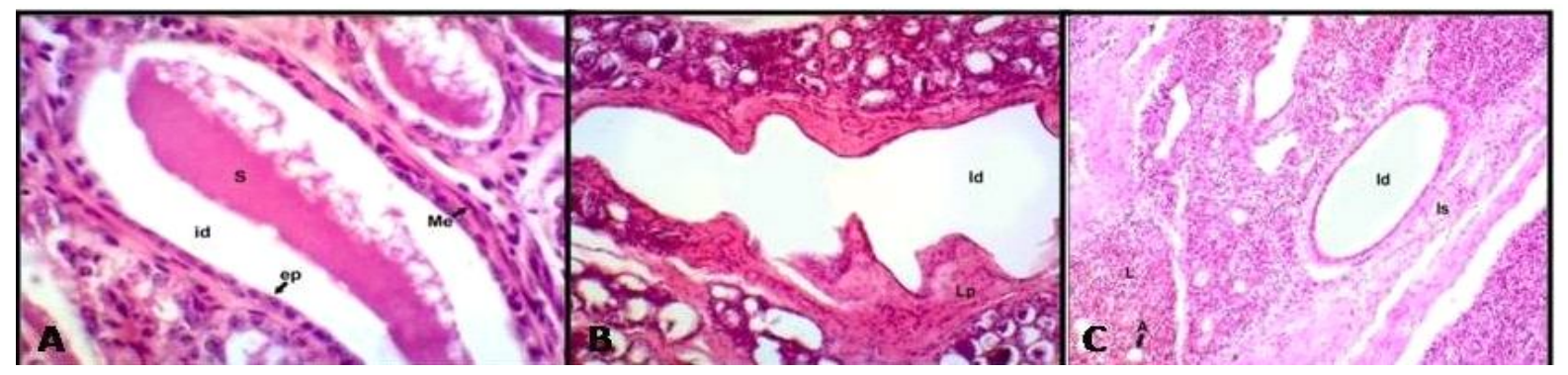

Fig 3: Photomicrograph- cross section of mammary gland showing intralobular duct (id), Interlobular duct (Id), low cuboidal epithelium (ep), Myoepithelial cell (Me), thick lamina propria (Lp), interlobular stroma (Is), alveoli (A) and lobule (L). A: Early lactating. H\&EX400, B: Late Lactating C: Non lactating H\&EX100.

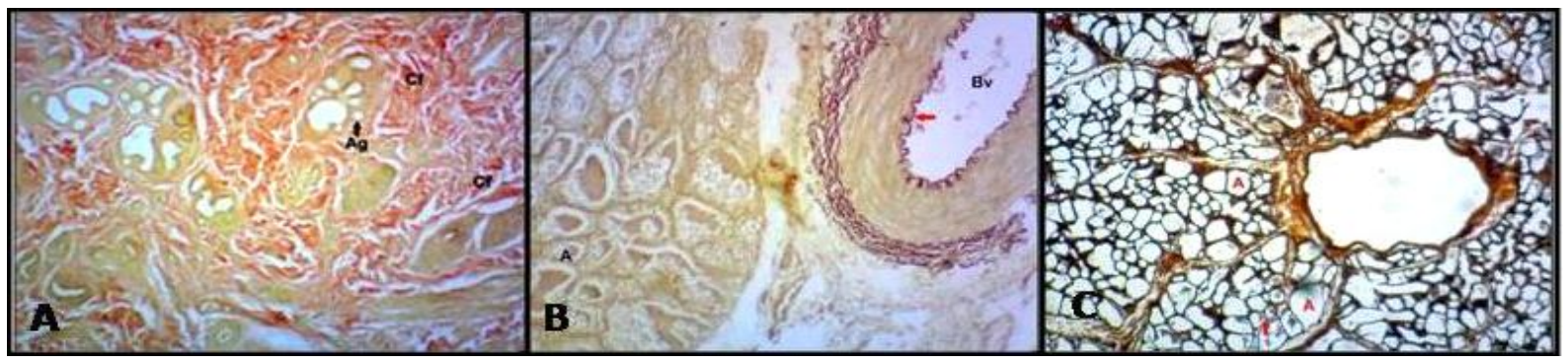

Fig 4: Photomicrograph- cross section of mammary gland showing distribution of fibers. A: Collagen fibers (Cf, Van Gieson's stainX40) around glandular tissue (Ag), B: Elastic fibers ( $\uparrow$, Weigert's elastic-VG stainX100) C: Reticular fibers ( $\uparrow$, Gomori's reticular stainX100) in the basement membrane of alveoli (A). 
Histomorphological Changes in the Mammary Gland of Local Indian Goat during Lactation Cycle

diameter of the lobule was $848.24 \mu \mathrm{m}$ and $310.10 \mu \mathrm{m}$, respectively. The alveoli were separated by large amount of intralobular connective tissue stroma. The average number of alveoli per lobule was 17 (Table 1). The majority of the alveoli were not appreciable in nonlactating goat. Instead of well defined alveoli, clusters of desquamated cells were seen and degenerated alveoli were also observed (Fig 2D). The present finding is in accordance with the report of Chaurasia (2010) in buffalo. Few of the alveoli were well defined and contained corpora amylacea. These alveoli were lined by single layer of cuboidal epithelium. The average height of the epithelium was $6.23 \mu \mathrm{m}$. Each alveoli on an average contained 11 cells. The nuclei were dark, small and spherical to flattened in shape. The cytoplasm of the alveolar epithelium was foamy. The foamy appearance of cytoplasm noted during present study could be attributed to the presence of lipid droplets in varying amount. Similar observations were recorded by Holst et al. (1987) and Sordillo and Nickerson (1988) in goats.

The mean diameter of the nuclei was $4.58 \mu \mathrm{m}$ (Table 1). Abundant thick interlobular stroma was present between the lobules (Fig 1E). It was evidenced pre-dominantly made up of dense collagen and coarse elastic fibers. Large interlobular ducts, large blood vessels, fat cells and fibroblasts were also seen in the interlobular stroma. It was more appreciable than in lactating goats and comprised of collagen fibers with few elastic fibers around the collapsed alveoli. Reticular fibers were evident in the basement membrane of the alveoli.

\section{Intralobular and interlobular ducts}

Intralobular ducts were lined by simple cuboidal epithelium. The long and short diameter of intralobular duct was 221.14 $\mu \mathrm{m}$ and $119.19 \mu \mathrm{m}$. Average height of the epithelium was $6.32 \mu \mathrm{m}$ (Table 2). The nuclei were small and spherical in shape. Interlobular ducts were lined by bistratified epithelium. The luminal surface was comprised of high cuboidal cells, whereas basal layer was composed of flattened epithelial cells. The average height of the epithelium was $4.62 \mu \mathrm{m}$ (Table 3). The nuclei were spherical in shape. There was increase in thickness of subepithelial connective tissue (Fig 3C).

\section{Corpora amylacea}

Corpora amylacea were seen in most of the alveoli during involution of mammary gland. The present finding is in support of Arnold and Weber (1977). They reported higher number of corpora amylacea during declining stage of lactation in cow. They stated that during declining stage of lactation, there is less secretory activity leading to less flow in the duct system and faster sloughing off epithelial cells causing favourable condition for increase in the rate of formation of corpora amylacea. However, Reid (1972) in cow, Katiyar and Chandra (1994) and Chaurasia (2010) in buffalo observed higher number of corpora amylacea in nonlactating nonpregnant animals.

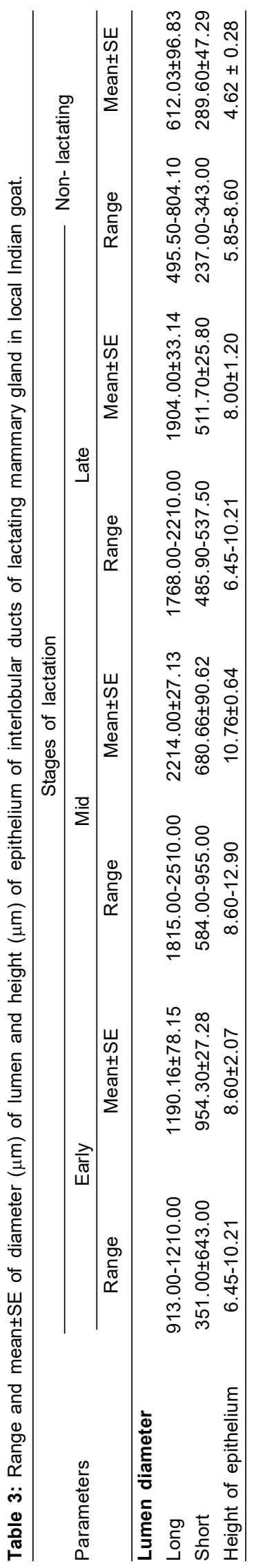




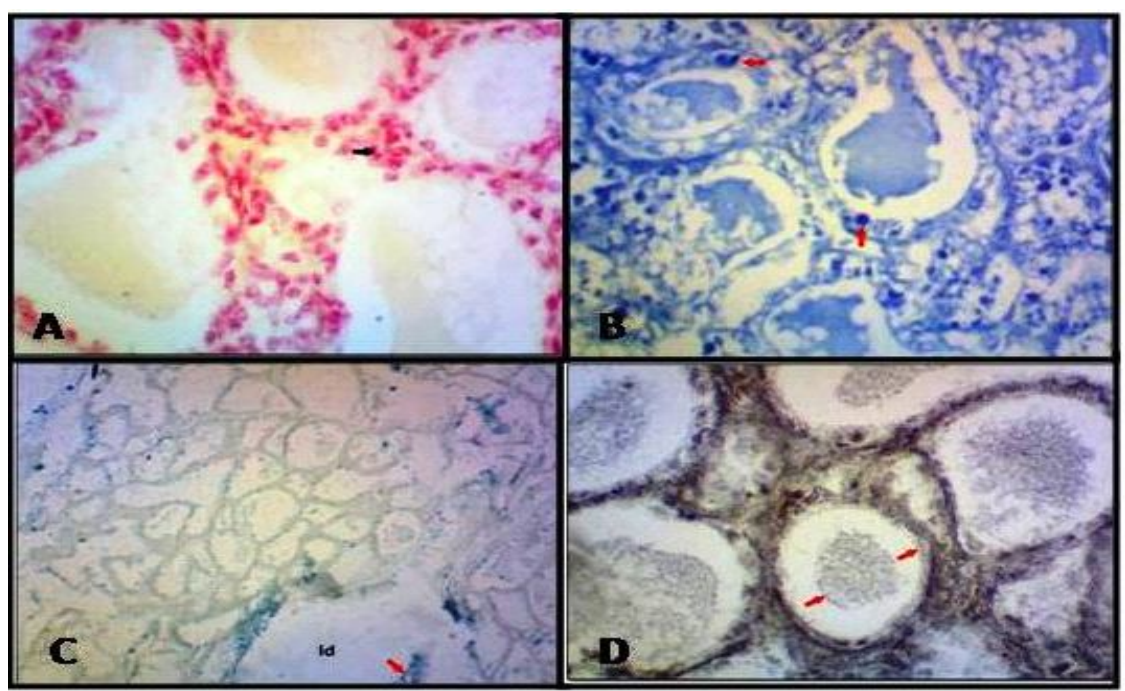

Fig 5: Photomicrograph- cross section of mammary gland showing distribution of A: glycogen $(\uparrow)$ in alveolar epithelium (Best carmine X100). B: mild to moderate reaction for protein $(\uparrow)$ in alveolar epithelium (Mercury bromophenol blue stainX400). C: Iron ( $\uparrow$ ) in luminal content of interlobular duct (Id) and in alveolar content (Perl's Prussian blue method X100). D: Calcium ( $\uparrow$ ) in alveolar epithelial cell and in alveolar content (Modified Vonkossa method X100).

According to Bacha and Bacha (2000) that the corpora amylacea is a concretion of casein and cell debris and common in advanced stage of lactation. Parekh (2002) reported that the corpora amylacea were rounded multilayered eosinophilic structures. These were mostly present in the lumen of the alveoli in the lactating gland and in the interstitial tissue in the nonlactating gland.

\section{Myoepithelium}

Spindle shaped myoepithelial cells were noticed between the cell membrane and basement membrane of alveoli and intralobular ducts. In mid lactation the myoepithelial cells were not discernible because of distended alveoli. In interlobular ducts longitudinally oriented myoepithelial cells were observed between the epithelium and basement membrane. The present finding is in accordance with the Aughey and Frye (2001) and Frappier (2007) in ruminants.

\section{Histochemistry}

Mild to moderate reaction for glycogen was observed in the alveolar epithelial cells in early and mid lactation (Fig 5A). Traces of glycogen was observed in the alveolar epithelium and epithelium of the interlobular duct in nonlactating goat. The epithelium of the interlobular duct showed moderate reaction in lactating but traces in nonlactating goat. The epithelial cells of alveoli showed moderate reaction for protein. The alveolar content was also mild positive for protein in lactating mammary gland (Fig 5B). Traces of weak reaction for protein was observed in alveoli of nonlactating mammary gland of goat. Precipitates of calcium found in alveolar epithelium and luminal content of lactating mammary gland and in alveolar epithelium of the lactating (Fig 5D). This observation is in agreement with findings of Katiyar (1982) in buffalo. Other structures were negative for calcium. Iron deposits were seen only in the secretory epithelium and alveolar content in mid lactation of goat (Fig 5C). However, it showed negative reaction in nonlactating goat. Other structures did not demonstrate any reaction for iron.

\section{CONCLUSION}

During early lactation the alveoli were small, oval or spherical with abundant lipid droplets in the luminal content. In mid lactation the alveoli became expanded, irregular with less lipid content. In late lactation again they became smaller and spherical with corpora amylacea in the lumen. These histomorphological changes in the secretory unit of the mammary gland reflect the lactation yield and milk composition during different stages of lactation. This observation in turn will be utilized by the scientists to improve the milk production and prevention of mastitis in goats.

\section{ACKNOWLEDGEMENT}

The authors are grateful to the Dean, College of Veterinary Sciences and Animal Husbandry, Jabalpur for providing necessary facilities.

\section{REFERENCES}

Arnold, J.P. and Weber, A.F. (1977). Occurrence and fate of corpora amylacea in bovine udder. American Journal of Veterinary Research. 38: 881.

Aughey, E. and Frye, F.L. (2001). Comparative Veterinary Histology with Clinical Correlates, Manson Publishing Ltd., UK. pp. 194-195.

Bacha, W.L. and Bacha, L.M. (2000). Color Atlas of Veterinary Histology, $2^{\text {nd }}$ edn., Lippincott Williams and Wilkins, Philadelphia. pp. 85-119.

Banerjee, G.C. (2011). A Textbook of Animal Husbandry. $8^{\text {th }}$ edn., Oxford and IBH Publ. 
Histomorphological Changes in the Mammary Gland of Local Indian Goat during Lactation Cycle

Chaurasia, D. (2010). Histochemical and Ultrastructural studies on Mammary Gland in Buffalo (Bubalus bualis). Ph. D. thesis. Maharashtra Animal and Fishery Science University, Nagpur, India Co. New Delhi. pp 932-979.

Dellmann, H.D. and Eurell, J. (1998). Textbook of Veterinary Histology, $5^{\text {th }}$ edn., Lippincott Williams and Wilkins, Philadelphia. pp 303-332.

Frappier, B.L. (2007). Epithelium. In Textbook of Veterinary Histology, $6^{\text {th }}$ edn., J.A. Eurell and B.L. Frappier (Ed.), Blackwell Publishing, Philadelphia. Pp. 17-30.

Gonzalo, C., Carriedo, J.A., Baro, J.A. and Primitivos, F. (1994). San factor influencing variation of test day milk yield, somatic cell count, fat and protein in dairy sheep. Journal of Dairy Science. 77: 1537-1542.

Holst, B.D., Hurley, W.L. and Nelson, D.R. (1987). Involution of the bovine mammary gland: Histological and ultrastructural changes. Journal of Dairy Science. 70: 935-944.

ICAR (2011). Handbook of Animal Husbandry. $3^{\text {rd }}$ edn. Indian Council of Agricultural Research, Krishi Anusandhan Bhawan, PUSA, New Delhi. Pp. 121-205.

Katiyar, R.S. (1982). Gross, Histological and Certain Histochemical Observation on the Mammary Gland of Buffalo (Bubalus bubalis) Ph. D. thesis, C.S.A. University of Agriculture and Technology, Mathura, India..

Katiyar, R.S. and Chandra, G. (1994). Histomorphological and certain histochemical observations on the corpora amylacea in the udder of buffalo (Bubalus bubalis). Indian Journal of Veterinary Anatomy. 6: 12-16.

Knight, C.H. and Wilde, C.J. (1993). Mammary cell changes during pregnancy and lactation. Livestock Production Science. 35: 3-19.

Mestawet, T.A., Girma, A., Ådnøy, T., Devold T.G., Narvhus, J.A. and Vegarud, G.E. (2012). Milk production, composition and variation at different lactation stages of four goat breeds in Ethiopia. Small Ruminant Research. 105: 176-181.
Michel, G. (1981). Histology of the cow's udder at individual stages of lactation. Monatshefte fur Veterinarmedizin. 36: 537541 (Cited from Vet. C.D.).

Parekh, B. (2002). Gross and microscopic studies on the udder of lactating and nonlactating, nonpregnant adult buffalo (Bubalus bubalis), M.V.Sc. thesis, Gujrat Agricultural University, Anand Campus, Anand, India.

Pearse, A.G.E. (1968). Histochemistry Theoretical and Applied. Vol. I. $3^{\text {rd }}$ end. Publ., Churchill Livingston, Edinburgh, London and New York. pp 610-710.

Reece, R.P. (1958). Mammary gland development and function. In Endocrinology of Reproduction. J.T. Velardo (Ed.) Oxford University Press, New York. Pp. 213- 240.

Reid, I.M. (1972). Corpora amylacea of bovine mammary gland: histochemical and electromicroscopic evidence for their amyloid nature. Journal of Comparative Pathology. 82: 409-413.

Riviere, N.A.M. (2007). Integument: In Textbook of Veterinary Histology, $6^{\text {th }}$ edn, $1^{\text {st }}$ Indian Reprint, J.A. Eurell and B.L. Frappier (Ed.) Blackwell Publishing, Philadelphia. pp. 320349.

Salama, A.A.K., Caja, G., Such, X., Casals, R. and Albanell, E. (2005). Effect of pregnancy and extended lactation on milk production in dairy goats milked once daily. Journal of Dairy Science. 88: 3894-3904.

Sordillo, L.M. and Nickerson, S.C. (1988). Morphologic changes in the bovine mammary gland during involution and lactogenesis. American Journal of Veterinary Research. 49: $1112-1120$

Strzałkowska, N., Jóźwik,A., Bagnicka, E., Krzyżewski, J. Horbańczuk, K., Pyzel, B. and Horbańczuk, J.O. (2009). Chemical composition, physical traits and fatty acid profile of goat milk as related to the stage of lactation. Animal Science Papers and Reports. 27: 311-320. 